Check for updates

Cite this: RSC Adv., 2017, 7, 19280

Received 20th January 2017

Accepted 18th March 2017

DOI: $10.1039 / \mathrm{c} 7 \mathrm{ra00879a}$

rsc.li/rsc-advances

\section{In situ DRIFT investigation on the photocatalytic NO oxidation mechanism with thermally exfoliated porous $\mathrm{g}-\mathrm{C}_{3} \mathrm{~N}_{4}$ nanosheets}

\author{
Hong Wang, ${ }^{a}$ Wenjie He, ${ }^{a}$ Xing'an Dong, ${ }^{a}$ Guangming Jiang, ${ }^{a}$ Yuxin Zhang, (D) ${ }^{b}$ \\ Yanjuan Sun ${ }^{\star a}$ and Fan Dong (iD *a
}

Bulk $\mathrm{g}-\mathrm{C}_{3} \mathrm{~N}_{4}$ suffers from a low surface area and high charge recombination rate. To advance the photocatalytic efficiency of $\mathrm{g}-\mathrm{C}_{3} \mathrm{~N}_{4}$, porous $\mathrm{g}-\mathrm{C}_{3} \mathrm{~N}_{4}$ nanosheets were prepared using a simple thermal exfoliation method. The effects of thermal exfoliation time on the microstructure and photocatalytic performance of $\mathrm{g}-\mathrm{C}_{3} \mathrm{~N}_{4}$ was investigated. Porous g- $\mathrm{C}_{3} \mathrm{~N}_{4}$ nanosheets treated for $4 \mathrm{~h}\left(\mathrm{C}_{3} \mathrm{~N}_{4}-4 \mathrm{~h}\right)$ exhibited a highly enhanced $\mathrm{NO}$ removal ratio of $51.2 \%$, which is 3.2 times higher than that of bulk $\mathrm{g}-\mathrm{C}_{3} \mathrm{~N}_{4}$. The enhanced activity of $\mathrm{C}_{3} \mathrm{~N}_{4}-4 \mathrm{~h}$ can be ascribed to an increased surface area and promoted charge separation. An in situ DRIFT investigation was applied to monitor the time-dependent NO adsorptionphotocatalysis process. Based on the observed reaction intermediates, a molecular-level mechanism for photocatalytic $\mathrm{NO}$ oxidation with porous $\mathrm{g}-\mathrm{C}_{3} \mathrm{~N}_{4}$ nanosheets was proposed.

\section{Introduction}

Graphitic carbon nitride $\left(\mathrm{g}-\mathrm{C}_{3} \mathrm{~N}_{4}\right)$ as a stable and eco-friendly semiconducting photocatalyst, has attracted extensive attention due to its diverse potential applications in environmental remediation, ${ }^{1}$ water splitting, ${ }^{2}$ electrocatalysis ${ }^{3,4}$ and water treatment. ${ }^{5-7}$ However, the low specific surface area and the high recombination rate of charge carriers resulted in the relatively low visible light photocatalytic activity and thus limited its practical application. ${ }^{8,9}$ In order to enhance the photocatalytic performance of $\mathrm{g}-\mathrm{C}_{3} \mathrm{~N}_{4}$, many strategies have been developed and applied. For instance, metal deposition, ${ }^{\mathbf{1 0 - 1 4}}$ metal/nonmetal doping, ${ }^{15,16}$ coupling with other semiconductors, ${ }^{17,18}$ and nanostructure engineering. Niu et al. ${ }^{19}$ developed a thermal exfoliation method using for porous graphene-like $\mathrm{g}-\mathrm{C}_{3} \mathrm{~N}_{4}$ with enhanced photocatalytic activity. Dong et al. ${ }^{20}$ investigated the effect of exfoliation temperature on the microstructure and photocatalytic performance of porous $\mathrm{g}-\mathrm{C}_{3} \mathrm{~N}_{4}$. It was found that the ultrathin exfoliated porous g- $\mathrm{C}_{3} \mathrm{~N}_{4}$ nanosheets were favorable for charge transfer and reactants diffusion.

Recently, g- $\mathrm{C}_{3} \mathrm{~N}_{4}$-based photocatalysts have been extensively reported the removal of NO. Dong et al. ${ }^{\mathbf{2 1 , 2 2}}$ immobilized the $\mathrm{g}$ -

${ }^{a}$ Chongqing Key Laboratory of Catalysis and New Environmental Materials, Engineering Research Center for Waste Oil Recovery Technology and Equipment of Ministry of Education, College of Environment and Resources, Chongqing Technology and Business University, 400067 Chongqing, China. E-mail: syhsyj@ 163.com; dfctbu@126.com; Fax: +86-23-62769785-605; Tel: +86-23-62769785-605

${ }^{b}$ College of Materials Science and Engineering, National Key Laboratory of Fundamental Science of Micro/Nano-Devices and System Technology, Chongqing University, Chongqing 400044, China
$\mathrm{C}_{3} \mathrm{~N}_{4}$ photocatalysts on $\mathrm{Al}_{2} \mathrm{O}_{3}$ ceramic foam for efficient photocatalytic NO removal. The holes, superoxide and hydroxyl radicals were found to be the main reactive species for NO oxidation. Wang et al. ${ }^{23}$ prepared $\mathrm{g}-\mathrm{C}_{3} \mathrm{~N}_{4}$ with honeycomb structures and applied them for enhanced photocatalytic NO removal. Li et al. ${ }^{24}$ fabricated the $\mathrm{g}-\mathrm{C}_{3} \mathrm{~N}_{4} /$ rutile-brookite $\mathrm{TiO}_{2-x} \mathrm{~N}_{y}$ composite photocatalysts for $\mathrm{NO}$ purification. However, the mechanism of photocatalytic NO oxidation with $\mathrm{g}$ $\mathrm{C}_{3} \mathrm{~N}_{4}$ has not been revealed as the reaction intermediates during photocatalysis are difficult for to be detected. Also, the effects of thermal exfoliation time on the microstructure of porous $g-\mathrm{C}_{3} \mathrm{~N}_{4}$ are still unknown.

Herein, we adopted the thermal exfoliation approach to prepare ultrathin porous $\mathrm{g}-\mathrm{C}_{3} \mathrm{~N}_{4}$ nanosheets. The effect of exfoliation time on the microstructure and photocatalytic performance of $\mathrm{g}-\mathrm{C}_{3} \mathrm{~N}_{4}$ investigated. The as-prepared porous $\mathrm{g}$ $\mathrm{C}_{3} \mathrm{~N}_{4}$ nanosheets were applied in visible light photocatalytic NO removal and exhibited enhanced activity. In situ DRIFT was employed to dynamically monitor the NO adsorption-photocatalysis process on the ultrathin porous $\mathrm{g}-\mathrm{C}_{3} \mathrm{~N}_{4}$ nanosheets. Based on the time-dependent evolution of reaction intermediates, a precise mechanism of photocatalytic NO oxidation was proposed. The present work could provide new insights into g$\mathrm{C}_{3} \mathrm{~N}_{4}$ photocatalysis mechanism for air purification.

\section{Experimental}

\subsection{Synthesis of photocatalyst}

2.1.1 Synthesis of $\mathbf{g}-\mathbf{C}_{3} \mathbf{N}_{4}$. All chemicals were analytical grade purity and used without further purification. $0.50 \mathrm{~g}$ of dicyanodiamine was placed in an alumina crucible with a cover 
and calcined at $550{ }^{\circ} \mathrm{C}$ for $2 \mathrm{~h}$ with a ramping rate of $15{ }^{\circ} \mathrm{C}$ $\min ^{-1}$, and then cooled slowly to room temperature. The product was collected after grinding into powder in an agate mortar for further use.

2.1.2 Synthesis of reoxidized ultrathin $\mathrm{g}-\mathrm{C}_{3} \mathbf{N}_{4} \cdot 0.5 \mathrm{~g}$ of the as-prepared $\mathrm{g}-\mathrm{C}_{3} \mathrm{~N}_{4}$ and $20 \mathrm{~mL}$ of deionized water were placed in an alumina crucible and calcined at $550{ }^{\circ} \mathrm{C}$ for different time $(2$, 4 and $6 \mathrm{~h}$ ) with heating rate of $15^{\circ} \mathrm{C} \min ^{-1}$ and then cooled slowly to room temperature. The product was collected as $\mathrm{C}_{3} \mathrm{~N}_{4}$ $2 \mathrm{~h}, \mathrm{C}_{3} \mathrm{~N}_{4}-4 \mathrm{~h}, \mathrm{C}_{3} \mathrm{~N}_{4}-6 \mathrm{~h}$ after grinding.

\subsection{Characterization}

The prepared $\mathrm{g}-\mathrm{C}_{3} \mathrm{~N}_{4}$ samples were examined by XRD (XRD: model D/max RA, Japan). The morphology structures for the obtained products were characterized by transmission electron microscopy (TEM: JEM-2010, Japan). The optical absorption spectra were recorded on a UV-vis diffuse reflection spectrophotometer (UV-2450, Shimadzu, Japan) in the diffuse reflectance mode, using $\mathrm{BaSO}_{4}$ as reflectance sample. The nitrogen adsorption-desorption isotherms were investigated in a nitrogen adsorption apparatus (ASAP 2020, USA) with products degassed at $150{ }^{\circ} \mathrm{C}$ prior to measurements. The photocurrent responses of the prepared samples were investigated in computer-controlled electrochemical apparatus.

\subsection{Visible light photocatalytic activity}

The photocatalytic activity of the obtained products was evaluated by oxidation of $\mathrm{NO}$ at ppb level in a continuous flow reactor. The volume of the rectangular reactor, made of stainless steel and covered with Saint-Glass, was $4.5 \mathrm{~L}(30 \mathrm{~cm} \times 15 \mathrm{~cm}$ $\times 10 \mathrm{~cm})$. A commercial tungsten halogen lamp $(150 \mathrm{~W})$ coupled with a $420 \mathrm{~nm}$ cutoff filter is utilized as the light source. For the test, $0.20 \mathrm{~g}$ of the photocatalyst spread on two sample dishes $(12.0 \mathrm{~cm}$ in diameter) was placed in the middle of the reactor. By mixing with flowing air, the NO concentration is diluted to $600 \mathrm{ppb}$ with a flow rate of $2.4 \mathrm{~mL} \mathrm{~min}^{-1}$ set by a mass flow controller. Then it was allowed to achieve an adsorptiondesorption equilibrium. A $\mathrm{NO}_{x}$ analyzer was used to continuously measure the NO concentration during test. According to the equation $(\eta \%)=\left(1-C / C_{0}\right) \times 100 \%\left(C\right.$ and $C_{0}$ represent the outlet and inlet NO concentrations, respectively), the NO removal rate $(\eta)$ can be determined.

\subsection{In situ DRIFTS study on photocatalytic NO oxidation process}

In situ DRIFTS measurements were conducted using the Tensor II FTIR spectrometer (Bruker) equipped with an in situ diffuse reflectance cell (Harrick), as shown in Fig. 1. Photocatalysts were put into the cell. First, He gas $\left(50 \mathrm{~mL} \mathrm{~min}^{-1}\right)$ was used to remove the residual hydrocarbons, $\mathrm{H}_{2} \mathrm{O}$ and $\mathrm{CO}_{2}$. The real-time FTIR spectrum after ventilation was utilized as background. Then, the reaction mixtures ( $25 \mathrm{~mL} \mathrm{~min}^{-1} \mathrm{NO}, 25 \mathrm{~mL} \mathrm{~min}{ }^{-1} \mathrm{O}_{2}$ ) were introduced into the cell. The NO adsorption on the catalysts was carried out for $20 \mathrm{~min}$. Next, photocatalysts were illuminated by visible light source (MVL-210, Japan) for $40 \mathrm{~min}$. The real-time FTIR spectra were detected every eight minutes.

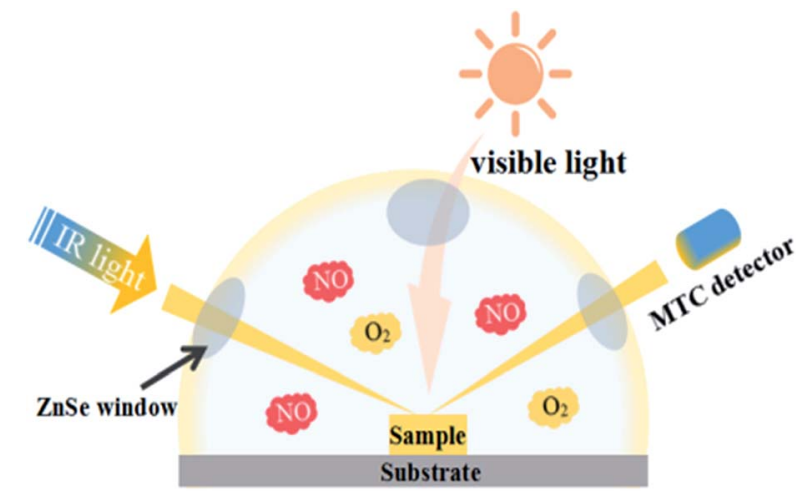

Fig. 1 Scheme of photoreaction cell used for in situ FT-IR data recording.

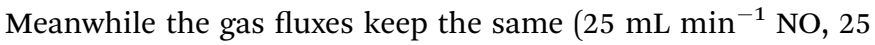
$\mathrm{mL} \min ^{-1} \mathrm{O}_{2}$ ). Finally, FTIR spectra were tested every two minutes with the same gas fluxes after turning off the light. The IR scanning range was $4000-600 \mathrm{~cm}^{-1}$ and $1900-1200 \mathrm{~cm}^{-1}$ was analyzed to present the photocatalytic oxidation process on porous $\mathrm{g}-\mathrm{C}_{3} \mathrm{~N}_{4}$ nanosheets.

\section{Results and discussion}

\subsection{Crystal structures}

Fig. 2 shows the XRD patterns of the prepared $\mathrm{g}-\mathrm{C}_{3} \mathrm{~N}_{4}$ samples treated for different time. All materials present two diffraction peaks, in agreement with the $\mathrm{g}-\mathrm{C}_{3} \mathrm{~N}_{4}$ (JCPDS card no. 87-1526), suggesting that the thermal treated $\mathrm{g}-\mathrm{C}_{3} \mathrm{~N}_{4}$ have similar crystal structure as their pristine bulk g- $\mathrm{C}_{3} \mathrm{~N}_{4}$. The strong peak, identified as the (002) peak of graphitic materials, can be attributed to the characteristic inter-layer stacking of the conjugated aromatic C-N units. ${ }^{25}$ This typical peak is shifted from $27.48^{\circ}$ for $\mathrm{C}_{3} \mathrm{~N}_{4}$ to $27.67^{\circ}$ for $\mathrm{C}_{3} \mathrm{~N}_{4}-6 \mathrm{~h}$, which can be ascribed to the decreased inter-layer spacing due to thermal exfoliation effect. Another low-angle reflection peak is found around $13.1^{\circ}$, which is assigned to (100) peak and corresponds to an inter-planar distance of $d=0.68 \mathrm{~nm}$ from the in-plane structural stacking

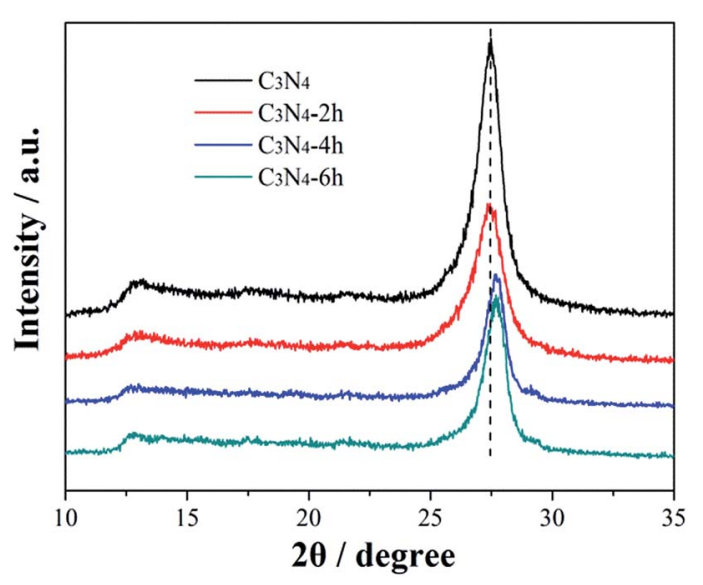

Fig. 2 XRD patterns of the $C_{3} N_{4}, C_{3} N_{4}-2 h, C_{3} N_{4}-4 h$ and $C_{3} N_{4}-6 h$. 
motif. ${ }^{25}$ Further, the (100) peak of $\mathrm{C}_{3} \mathrm{~N}_{4}-4 \mathrm{~h}$ and $\mathrm{C}_{3} \mathrm{~N}_{4}-6 \mathrm{~h}$ shifts to a lower angle of $12.7^{\circ}$, demonstrating that the planar size is increased during thermal exfoliation. ${ }^{26}$

\subsection{Morphological structures}

The morphology of the samples treated at different time was analyzed by TEM as showed in Fig. 3. Fig. 3a shows that the bulk $\mathrm{C}_{3} \mathrm{~N}_{4}$ has a bulk layered structure. The enlarged view in Fig. $3 \mathrm{~b}$ shows that the bulk $\mathrm{C}_{3} \mathrm{~N}_{4}$ exhibits orderly stacked layers and a typical nonporous architecture. Compared to the pristine bulk
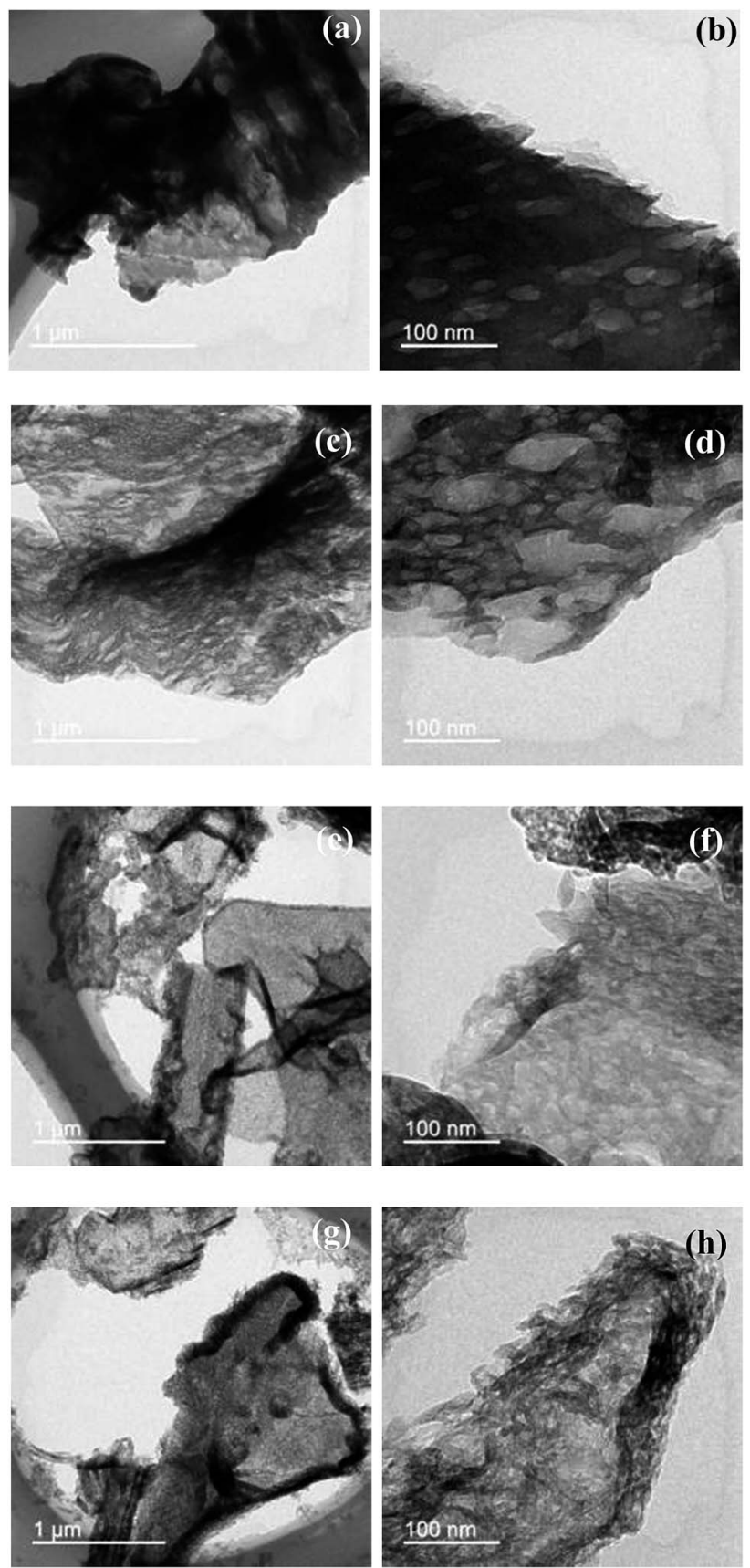

Fig. 3 TEM images of $C_{3} N_{4}(a, b), C_{3} N_{4}-2 h(c, d), C_{3} N_{4}-4 h(e, f)$ and $\mathrm{C}_{3} \mathrm{~N}_{4}-6 \mathrm{~h}(\mathrm{~g}, \mathrm{~h})$ g- $\mathrm{C}_{3} \mathrm{~N}_{4}$ samples, the thermally treated g- $\mathrm{C}_{3} \mathrm{~N}_{4}$ samples appear as thin and porous structure (Fig. $3 \mathrm{c}$ to $\mathrm{h}$ ). This can be understood as the pristine bulk $\mathrm{g}-\mathrm{C}_{3} \mathrm{~N}_{4}$ samples were exfoliated into thin layers during thermal treatment. The bulk layered structure of $\mathrm{g}^{-} \mathrm{C}_{3} \mathrm{~N}_{4}$ has typical $\mathrm{CN}$ layers linked together by weak van der Waals forces and hydrogen bonds. The van der Waals forces and hydrogen bonds are not stable enough against thermal oxidation process in air, and the layers of the $\mathrm{CN}$ unit would be gradually oxidized away from the bulk material in a layer-bylayer manner. ${ }^{20}$ As showed in Fig. $3 \mathrm{e}$ to $\mathrm{h}$, after thermal treatment for a long time, the $\mathrm{C}_{3} \mathrm{~N}_{4}-4 \mathrm{~h}$ and $\mathrm{C}_{3} \mathrm{~N}_{4}-6 \mathrm{~h}$ sample exhibit ultra-thin and porous layered structure. The AFM image (Fig. 4a) reflects that $\mathrm{C}_{3} \mathrm{~N}_{4}-4 \mathrm{~h}$ has the nanosheets structure. As showed in Fig. 4b, the nanosheets thickness is $2.1 \mathrm{~nm}$.

\subsection{BET surface areas and pore structure}

The detailed information about the specific surface areas and porosity of the $\mathrm{C}_{3} \mathrm{~N}_{4}, \mathrm{C}_{3} \mathrm{~N}_{4}-2 \mathrm{~h}, \mathrm{C}_{3} \mathrm{~N}_{4}-4 \mathrm{~h}$ and $\mathrm{C}_{3} \mathrm{~N}_{4}-6 \mathrm{~h}$ was accessed by nitrogen absorption-desorption isotherms and Barrett-Joyner-Halenda (BJH) pore-size distribution are measured (Fig. 5 and Table 1). Fig. 5a shows that the above samples belong to type IV in BDDT classification shape of isotherms with a H3-type hysteresis loop in the IUPAC classification, suggesting the presence of slit-like mesopores. As showed in Fig. $5 \mathrm{~b}$, the $\mathrm{C}_{3} \mathrm{~N}_{4}-4 \mathrm{~h}$ and $\mathrm{C}_{3} \mathrm{~N}_{4}-6 \mathrm{~h}$ are abundant in large mesopores (22 to $60 \mathrm{~nm}$ ) and small mesopores $(3.79 \mathrm{~nm})$.

The specific surface area, pore volume, peak pore size, and NO removal ratios are summarized in Table 1 . The $\mathrm{C}_{3} \mathrm{~N}_{4}-4 \mathrm{~h}$ has a higher specific surface area $\left(122 \mathrm{~m}^{2} \mathrm{~g}^{-1}\right)$ and correspondingly larger pore volume $\left(0.55 \mathrm{~cm}^{3} \mathrm{~g}^{-1}\right)$ than the others. Generally, the introduction of mesoporosity into $\mathrm{g}-\mathrm{C}_{3} \mathrm{~N}_{4}$ leads to increased
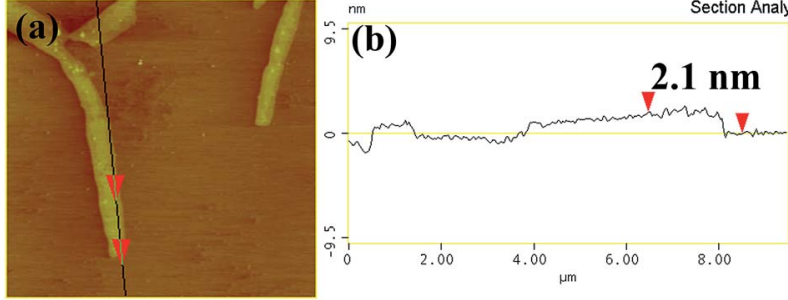

Fig. 4 The typical AFM image (a) and the corresponding thickness analysis results (b) of $\mathrm{C}_{3} \mathrm{~N}_{4}-4 \mathrm{~h}$.
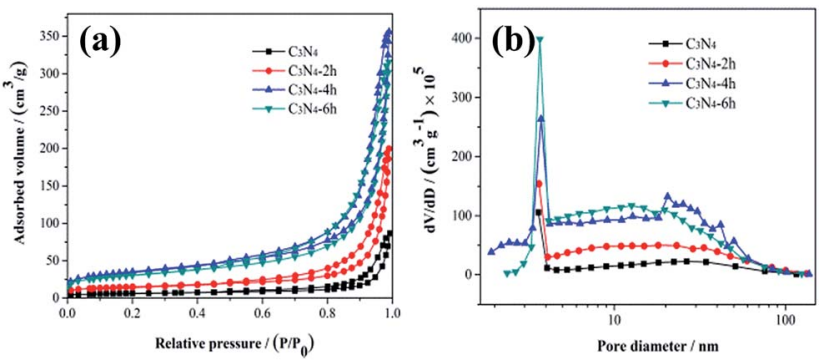

Fig. $5 \mathrm{~N}_{2}$ adsorption-desorption isotherms (a) and the pore-size distribution curves (b) of the $\mathrm{C}_{3} \mathrm{~N}_{4}, \mathrm{C}_{3} \mathrm{~N}_{4}-2 \mathrm{~h}, \mathrm{C}_{3} \mathrm{~N}_{4}-4 \mathrm{~h}$ and $\mathrm{C}_{3} \mathrm{~N}_{4}-6 \mathrm{~h}$. 
Table 1 The $S_{\mathrm{BET}}$, total pore volume, peak pore size and $\mathrm{NO}$ removal ratio for $\mathrm{C}_{3} \mathrm{~N}_{4}, \mathrm{C}_{3} \mathrm{~N}_{4}-2 \mathrm{~h}, \mathrm{C}_{3} \mathrm{~N}_{4}-4 \mathrm{~h}$ and $\mathrm{C}_{3} \mathrm{~N}_{4}-6 \mathrm{~h}$

\begin{tabular}{lllll}
\hline $\begin{array}{l}\text { Sample } \\
\text { name }\end{array}$ & $\begin{array}{l}S_{\mathrm{BET}} \\
\left(\mathrm{m}^{2} \mathrm{~g}^{-1}\right)\end{array}$ & $\begin{array}{l}\text { Total pore volume } \\
\left(\mathrm{cm}^{3} \mathrm{~g}^{-1}\right)\end{array}$ & $\begin{array}{l}\text { Peak pore } \\
\text { size }(\mathrm{nm})\end{array}$ & $\begin{array}{l}\text { NO removal } \\
\text { ratio }(\%)\end{array}$ \\
\hline $\mathrm{C}_{3} \mathrm{~N}_{4}$ & 20 & 0.13 & $3.6 / 26.5$ & 16.0 \\
$\mathrm{C}_{3} \mathrm{~N}_{4}-2 \mathrm{~h}$ & 50 & 0.31 & $3.6 / 18.0$ & 47.8 \\
$\mathrm{C}_{3} \mathrm{~N}_{4}-4 \mathrm{~h}$ & 122 & 0.55 & $3.7 / 20.5$ & 51.2 \\
$\mathrm{C}_{3} \mathrm{~N}_{4}-6 \mathrm{~h}$ & 105 & 0.49 & $3.6 / 12.6$ & 49.7
\end{tabular}

surface areas. ${ }^{20}$ The enlarged surface area would be beneficial for mass transfer and provide more active sites for photocatalysis reaction. ${ }^{20}$

\subsection{Optical properties and band gap structure}

As showed in the UV-vis DRS spectra (Fig. 6a), all the samples show an absorption edge (420-460 $\mathrm{nm}$ ) in the visible light region. The absorption spectra of the samples thermal treated at different time exhibit an obvious blue shifted in comparison with the original g- $\mathrm{C}_{3} \mathrm{~N}_{4}$. The band gap energy of $\mathrm{C}_{3} \mathrm{~N}_{4}, \mathrm{C}_{3} \mathrm{~N}_{4}-2 \mathrm{~h}$, $\mathrm{C}_{3} \mathrm{~N}_{4}-4 \mathrm{~h}$ and $\mathrm{C}_{3} \mathrm{~N}_{4}-6 \mathrm{~h}$ are calculated to be 2.39, 2.46, 2.58 and $2.55 \mathrm{eV}$ (Fig. 6b). The enlarged band gap for the thin layered samples can be attributed to the well-known quantum confinement effect by shifting the conduction and valence band edges in opposite directions. ${ }^{27}$ The increase in band gap energy is beneficial for the enhancement of redox ability of the charge carriers generated by $\mathrm{g}-\mathrm{C}_{3} \mathrm{~N}_{4}$.

The separation efficiency of photogenerated carriers is investigated by the photocurrent measurement. ${ }^{28}$ As shown in the wavelength-dependent photocurrent density in Fig. 7, in contrast to the pristine $\mathrm{C}_{3} \mathrm{~N}_{4}$ with a low photocurrent density under visible-light irradiation, the $\mathrm{C}_{3} \mathrm{~N}_{4}-4 \mathrm{~h}$ shows a remarkably improved photocurrent density, which indicates the enhanced charge separation efficiency of $\mathrm{C}_{3} \mathrm{~N}_{4}-4 \mathrm{~h}$ sample. This could be attributed to ultra-thin layered structure of $\mathrm{C}_{3} \mathrm{~N}_{4}-4 \mathrm{~h}$ sample (Fig. 3e and f), which could promote the charge migration and separation. ${ }^{\mathbf{1 9 , 2 0}}$

\subsection{Visible light photocatalytic activity and stability for NO removal}

To demonstrate the photocatalytic activities of all the obtained samples for air purification, visible light photocatalytic removal
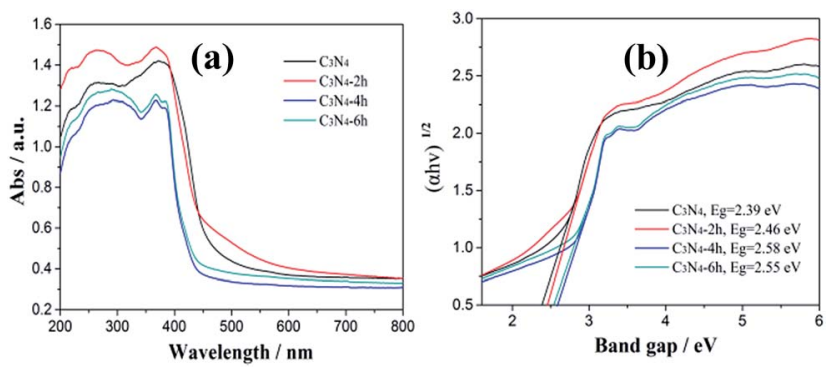

Fig. 6 UV-vis diffuse reflectance spectra (a) and band gap energies (b) of the $\mathrm{C}_{3} \mathrm{~N}_{4}, \mathrm{C}_{3} \mathrm{~N}_{4}-2 \mathrm{~h}, \mathrm{C}_{3} \mathrm{~N}_{4}-4 \mathrm{~h}$ and $\mathrm{C}_{3} \mathrm{~N}_{4}-6 \mathrm{~h}$.

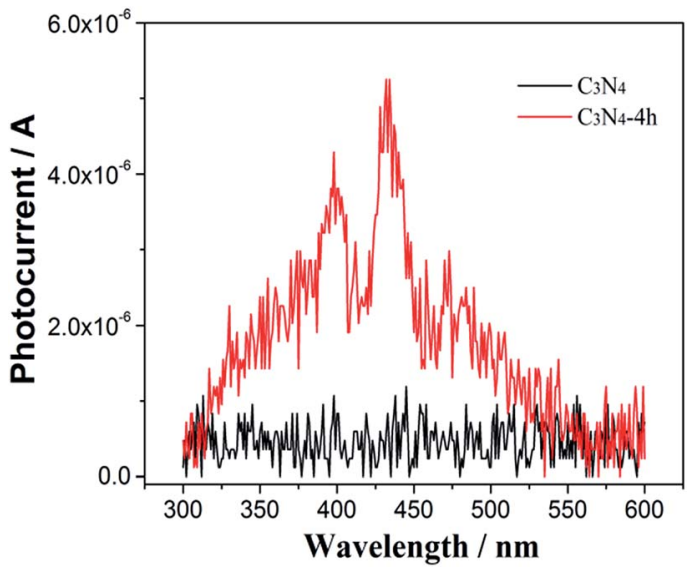

Fig. 7 Wavelength-dependent photocurrent of the $\mathrm{C}_{3} \mathrm{~N}_{4}, \mathrm{C}_{3} \mathrm{~N}_{4}-2 \mathrm{~h}$, $\mathrm{C}_{3} \mathrm{~N}_{4}-4 \mathrm{~h}$ and $\mathrm{C}_{3} \mathrm{~N}_{4}-6 \mathrm{~h}$.

of NO in air in a continuous reactor was carried out. ${ }^{29-31}$ As showed in Fig. 8, the variation of NO concentration $\left(C / C_{0} / \%\right)$ with irradiation time over the $\mathrm{g}-\mathrm{C}_{3} \mathrm{~N}_{4}$ samples. After irradiation for $30 \mathrm{~min}$, the NO removal ratio of the $\mathrm{C}_{3} \mathrm{~N}_{4}, \mathrm{C}_{3} \mathrm{~N}_{4}-2 \mathrm{~h}, \mathrm{C}_{3} \mathrm{~N}_{4}-4 \mathrm{~h}$ and $\mathrm{C}_{3} \mathrm{~N}_{4}-6 \mathrm{~h}$ was $16.0 \%, 47.8 \%$ and $49.7 \%$, respectively. Unprecedentedly, the $\mathrm{C}_{3} \mathrm{~N}_{4}-4 \mathrm{~h}$ exhibited a dramatically enhanced NO removal ratio of 51.2\%, 3.2 times higher than that of the bulk $\mathrm{g}-\mathrm{C}_{3} \mathrm{~N}_{4}$. The remarkably improved photocatalytic activities of the ultra-thin $\mathrm{g}-\mathrm{C}_{3} \mathrm{~N}_{4}$ demonstrated above can be explained as the synergistic effects of increased surface area and pore structure (Fig. 5b and Table 1), enhanced redox ability (Fig. 6b) and improvement in effective charge separation (Fig. 7).

The large surface area can increase the number of possible reactive sites for adsorption and diffusion of reactant molecules. ${ }^{19}$ The ultra-thin layered structure of $\mathrm{C}_{3} \mathrm{~N}_{4}-4 \mathrm{~h}$ could promote carrier transfer and separation and thus more carriers can take part in the photocatalytic reaction. The band gap of the $\mathrm{C}_{3} \mathrm{~N}_{4}-4 \mathrm{~h}$ is increased by $0.2 \mathrm{eV}$, which could enhance the redox ability of charge carriers generated in the $\mathrm{C}_{3} \mathrm{~N}_{4}-4$ h. The significant role of a marginally increased band gap in promoting photo catalytic activities has also been reported from

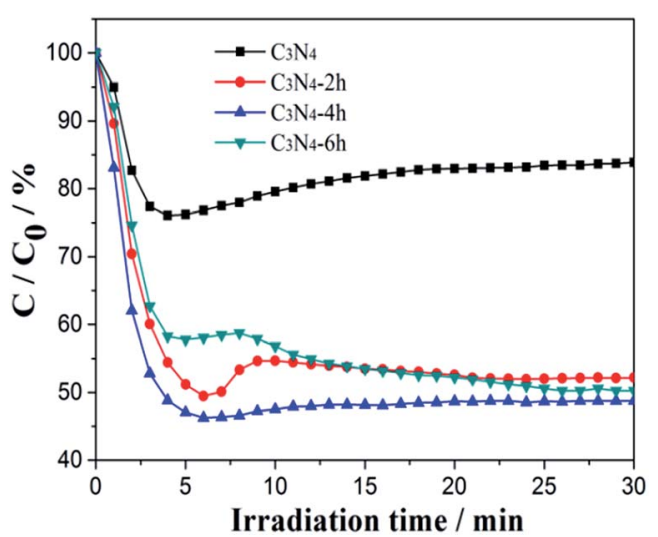

Fig. 8 Visible light photocatalytic activities of the $\mathrm{C}_{3} \mathrm{~N}_{4}, \mathrm{C}_{3} \mathrm{~N}_{4}-2 \mathrm{~h}$, $\mathrm{C}_{3} \mathrm{~N}_{4}-4 \mathrm{~h}$ and $\mathrm{C}_{3} \mathrm{~N}_{4}-6 \mathrm{~h}$. 
$\mathrm{Cs}_{0.68} \mathrm{Ti}_{1.83} \mathrm{O}_{4-x} \mathrm{~N}_{x}$ and faceted anatase $\mathrm{TiO}_{2}$ crystals. ${ }^{32-34}$ The above favorable factors co-contribute to the substantially improved photocatalytic activity of the ultra-thin $\mathrm{g}-\mathrm{C}_{3} \mathrm{~N}_{4}$.

\subsection{In situ DRIFT study on the adsorption and photocatalytic NO reaction on $\mathrm{g}-\mathrm{C}_{3} \mathrm{~N}_{4}$ under visible light}

3.6.1 NO adsorption and reaction on bulk $\mathrm{g}-\mathrm{C}_{3} \mathbf{N}_{4}$. Fig. 9a shows the IR spectra of $\mathrm{NO}$ adsorbed on bulk $\mathrm{g}-\mathrm{C}_{3} \mathrm{~N}_{4}$. In the region of $900-1200 \mathrm{~cm}^{-1}$ and $3600-3750 \mathrm{~cm}^{-1}$, several absorption bands were formed after the contact of bulk $\mathrm{g}-\mathrm{C}_{3} \mathrm{~N}_{4}$ with gaseous $\mathrm{NO}$ and $\mathrm{O}_{2}$ at $25{ }^{\circ} \mathrm{C}$. In the first $2 \mathrm{~min}$, the adsorption of $\mathrm{NO}$ on bulk $\mathrm{g}-\mathrm{C}_{3} \mathrm{~N}_{4}$ resulted in the formation of iso- $\mathrm{N}_{2} \mathrm{O}_{4}(917$ $\left.\mathrm{cm}^{-1}\right)^{36}$ and $\mathrm{N}_{2} \mathrm{O}\left(1121 \mathrm{~cm}^{-1}\right) \cdot{ }^{36}$ In the high-frequency region (3600-3750 $\left.\mathrm{cm}^{-1}\right)$, plenty of adsorption bands can be observed after $4 \mathrm{~min}$. All these bands (3604, 3623, 3635, 3663, 3683, 3696, 3717,3729 and $3740 \mathrm{~cm}^{-1}$ ) could attribute to $\mathrm{NO}_{2} \cdot{ }^{36}$ Oxidation of $\mathrm{NO}$ with $\mathrm{O}_{2}$ on bulk $\mathrm{g}-\mathrm{C}_{3} \mathrm{~N}_{4}$ caused the formation of $\mathrm{NO}_{2}$. As time passed, the intensity of these bands is increased, as more amount of NO are adsorbed on bulk g- $\mathrm{C}_{3} \mathrm{~N}_{4}$ and quickly transformed to $\mathrm{NO}_{2}$. Especially, in the first $4 \mathrm{~min}$, the adsorbed $\mathrm{NO}_{2}$ may be consumed and transformed to $\mathrm{N}_{2} \mathrm{O}_{4}$, resulting in no obvious changes of spectra in the region of $\mathrm{NO}_{2}$ (3600-3750
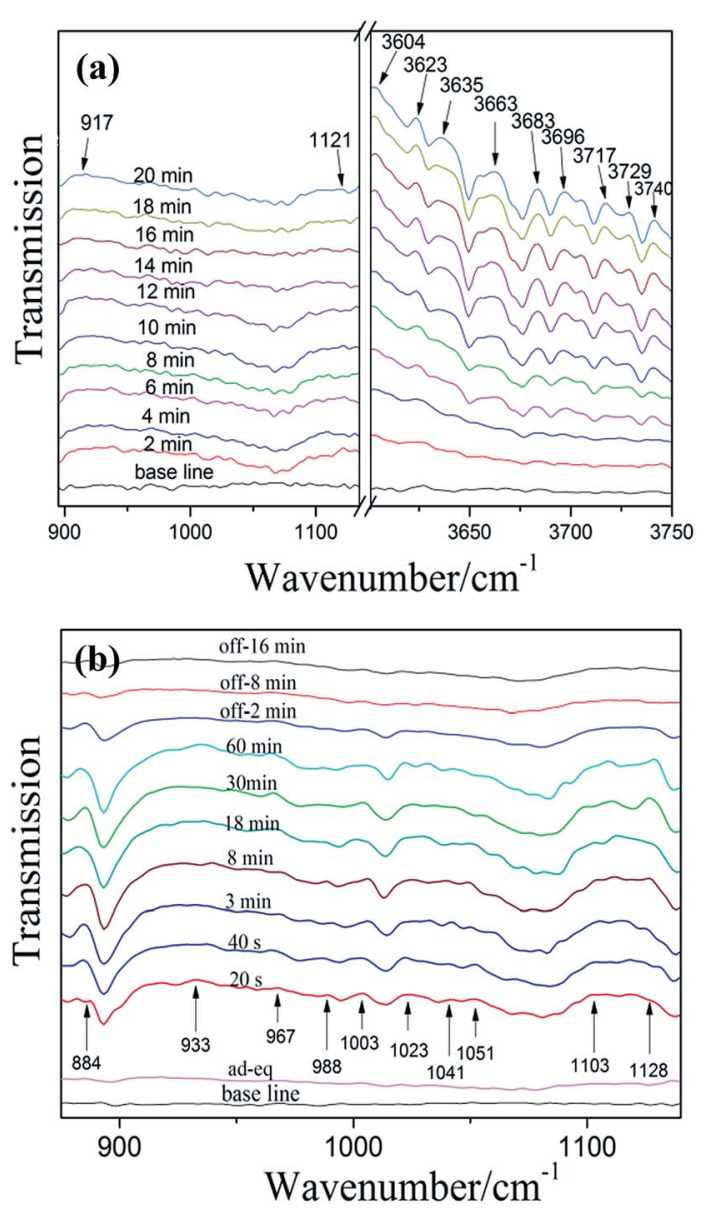

Fig. 9 In situ DRIFT spectra of adsorption (a) and photocatalytic reaction (b) on bulk $\mathrm{g}-\mathrm{C}_{3} \mathrm{~N}_{4}$ ("ad-eq" represents adsorptionequilibrium). $\left.\mathrm{cm}^{-1}\right) .{ }^{37}$ Some investigators found that the band of $\mathrm{N}_{2} \mathrm{O}$ increased at the beginning of $\mathrm{NO}$ adsorption and then decreased over time. ${ }^{37}$ Noteworthy, similar results have been observed in this work. This may attribute to the NO of N-NO was further oxidation and formed $\mathrm{NO}_{2}$, causing consumption of $\mathrm{N}_{2} \mathrm{O}$. The probable adsorption processes are proposed as follows (Table 2). ${ }^{36,38}$

$$
\begin{gathered}
\mathrm{NO}+\mathrm{e}_{(\mathrm{CN})}^{-} \rightarrow \mathrm{NO}^{-}+\mathrm{e}_{(\mathrm{CN})} \rightarrow \mathrm{NO}^{2-} \\
\mathrm{NO}+\mathrm{O}_{2} \rightarrow \mathrm{NO}_{2} \rightleftharpoons \mathrm{N}_{2} \mathrm{O}_{4} \\
\mathrm{NO}+\mathrm{O}_{2} \rightarrow \mathrm{NO}_{3}+\mathrm{NO}_{2} \rightarrow \mathrm{N}_{2} \mathrm{O}_{5} \\
\mathrm{NO}+\mathrm{NO}_{2} \rightarrow \mathrm{N}_{2} \mathrm{O}_{3} \\
\mathrm{NO}+\mathrm{N}_{(\mathrm{CN})} \rightarrow \mathrm{N}_{2} \mathrm{O}
\end{gathered}
$$

Fig. 9b shows the spectra of photocatalytic NO oxidation on bulk $\mathrm{g}-\mathrm{C}_{3} \mathrm{~N}_{4}$ during visible irradiation in time sequence. The spectrum of "ad-ep" is the same as that of " 20 min" in Fig. 9a, at which $\mathrm{NO}$ and $\mathrm{O}_{2}$ adsorption is reached equilibrium after introducing $\mathrm{NO}$ and $\mathrm{O}_{2}$ in the dark. The irradiation with visible light for $20 \mathrm{~s}$ results in new absorption bands and causes significant changes in the region of $850-1150 \mathrm{~cm}^{-1}$. Obviously, several new adsorption bands appear. These bands belong to reaction intermediates $\left(\mathrm{NO}^{2-}, \mathrm{N}_{2} \mathrm{O}_{3}\right.$ and $\left.\mathrm{NO}^{-}\right)$and final products $\left(\mathrm{NO}_{2}{ }^{-}\right.$and $\left.\mathrm{NO}_{3}{ }^{-}\right)$. This indicates that some kinds of photogenerated active species induce the photocatalytic reaction and lead to the conversion of NO to intermediates and end products. According to previous work, the main reactive species for $\mathrm{g}-\mathrm{C}_{3} \mathrm{~N}_{4}$ are superoxide and hydroxyl radicals. ${ }^{42}$ The absorption bands at $884,967,1103$ and $1128 \mathrm{~cm}^{-1}$ can be indexed to $\mathrm{NO}^{2-}, \mathrm{N}_{2} \mathrm{O}_{3}, \mathrm{NO}^{-}$and $\mathrm{N}_{2} \mathrm{O}$, respectively. ${ }^{36,41}$ The band at 933, 1003, 1023, 1041 and $1051 \mathrm{~cm}^{-1}$ can be assigned to nitrates $\left(\mathrm{NO}_{3}{ }^{-}\right) \cdot{ }^{36,39,40}$ In addition, the $\mathrm{NO}_{2}{ }^{-}$was detected at $988 \mathrm{~cm}^{-1} \cdot{ }^{39}$ Noteworthy, the peaks of formative species gradually disappear after visible-light off. However, we can see from the spectrum of "off-16 min", some weak adsorption peaks could be detected as some reaction species are still adsorbed on the surface of the photocatalyst. $^{22,43}$ The mechanism of photocatalytic NO

Table 2 Assignments of the FT-IR bands observed upon adsorptionreaction of $\mathrm{NO}$ on bulk $\mathrm{g}-\mathrm{C}_{3} \mathrm{~N}_{4}$ and $\mathrm{C}_{3} \mathrm{~N}_{4}-4 \mathrm{~h}$ followed by visible irradiation

\begin{tabular}{lll}
\hline Wavenumbers $\left(\mathrm{cm}^{-1}\right)$ & Assignment & References \\
\hline 884 & $\mathrm{NO}^{2-}$ & 36 \\
$933,1003,1009,1023,1041$, & $\mathrm{NO}^{3-}$ & 36,39 and 40 \\
$\begin{array}{l}1051,1002,1038 \\
988\end{array}$ & $\mathrm{NO}^{2-}$ & 39 \\
$1099,1103,1113$ & $\mathrm{NO}^{-} / \mathrm{NOH}$ & 41 \\
961,967 & sym- $\mathrm{N}^{2} \mathrm{O}^{3}$ & 36 \\
$1121,1128,1130$ & $\mathrm{~N}_{2} \mathrm{O}$ & \\
917,914 & $\mathrm{iso}^{-} \mathrm{N}_{2} \mathrm{O}_{4}$ & \\
$2821,2881,2945,3463,3603-3742$ & $\mathrm{NO}_{2}$ & \\
866,902 & $\mathrm{~N}_{2} \mathrm{O}_{5}$ &
\end{tabular}


oxidation reactions are proposed as follows $\left(\mathrm{NO}_{x}=\mathrm{NO}^{2-}, \mathrm{N}_{2} \mathrm{O}_{3}\right.$, $\mathrm{NO}^{-}$and $\left.\mathrm{N}_{2} \mathrm{O}\right){ }^{22}$

$$
\begin{aligned}
& \text { g- } \mathrm{C}_{3} \mathrm{~N}_{4}+h \nu \rightarrow \mathrm{e}^{-}+\mathrm{h}^{+} \\
& \mathrm{e}^{-}+\mathrm{O}_{2} \rightarrow{ }^{\cdot} \mathrm{O}_{2}^{-} \\
& \mathrm{O}_{2}^{-}+2 \mathrm{H}^{+}+\mathrm{e}^{-} \rightarrow \mathrm{H}_{2} \mathrm{O}_{2} \\
& \mathrm{H}_{2} \mathrm{O}_{2}+\mathrm{e}^{-} \rightarrow^{\cdot} \mathrm{OH}+\mathrm{OH}^{-} \\
& \mathrm{NO}_{x}+{ }^{\cdot} \mathrm{O}_{2}{ }^{-} \rightarrow \mathrm{NO}_{2}{ }^{-} / \mathrm{NO}_{3}{ }^{-} \\
& 2^{\cdot} \mathrm{OH}+\mathrm{NO}_{x} \rightarrow \mathrm{NO}_{2}+\mathrm{H}_{2} \mathrm{O} \\
& \mathrm{NO}_{2}+{ }^{\cdot} \mathrm{OH} \rightarrow \mathrm{NO}_{2}{ }^{-} / \mathrm{NO}_{3}{ }^{-}+\mathrm{H}^{+} \\
& \mathrm{NO}_{2}{ }^{-}+{ }^{\cdot} \mathrm{OH} /{ }^{\circ} \mathrm{O}_{2}{ }^{-} \rightarrow \mathrm{NO}_{3}{ }^{-}
\end{aligned}
$$

3.6.2 NO adsorption and reaction on exfoliated porous $\mathrm{g}$ $\mathbf{C}_{3} \mathbf{N}_{4}$ nanosheets. Fig. 10a shows the spectra of NO adsorbed on exfoliated porous $\mathrm{g}-\mathrm{C}_{3} \mathrm{~N}_{4}$ nanosheets $\left(\mathrm{C}_{3} \mathrm{~N}_{4}-4 \mathrm{~h}\right)$. The adsorption
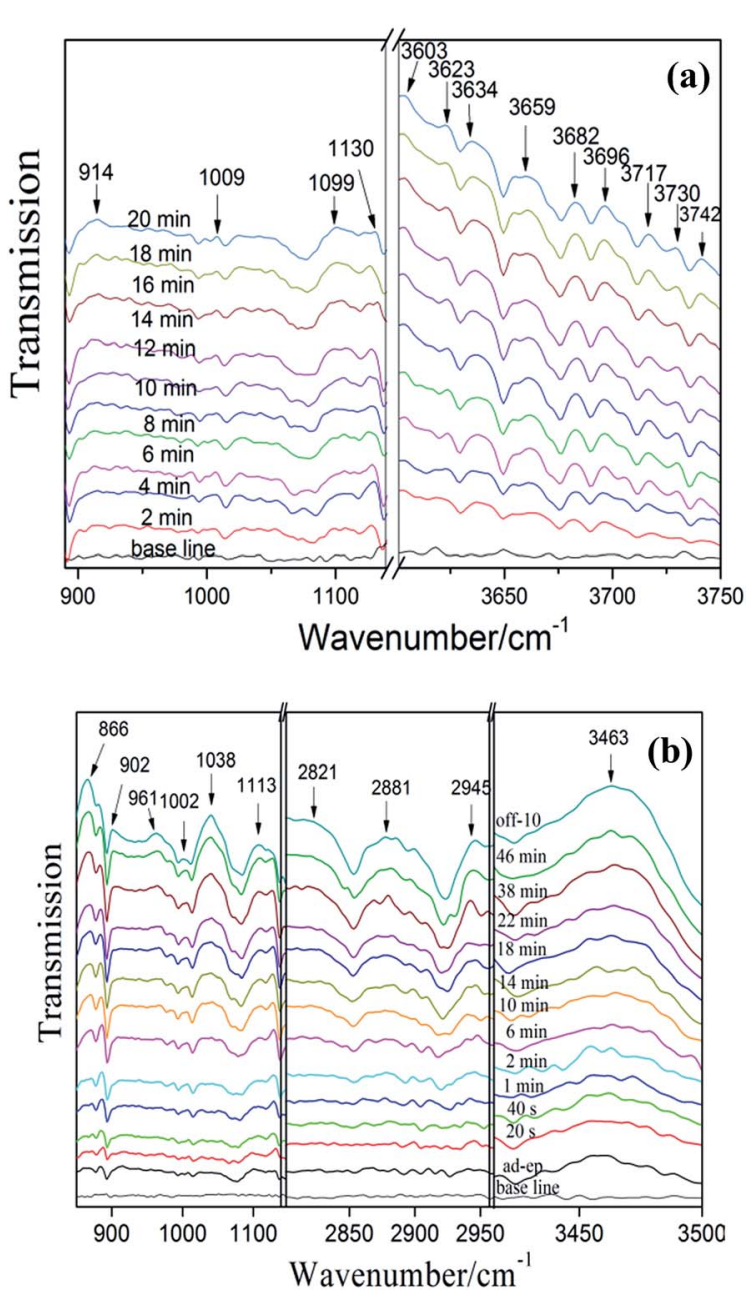

Fig. 10 In situ DRIFT spectra of adsorption (a) and photocatalytic reaction (b) on $\mathrm{C}_{3} \mathrm{~N}_{4}-4 \mathrm{~h}$. peaks in Fig. 9a appear in Fig. 10a as well. In addition, the new bands at 1009 and $1099 \mathrm{~cm}^{-1}$ were assigned to nitrates and $\mathrm{NO}^{-}{ }^{36}$ Obviously, the bands assigned to $\mathrm{NO}_{2}$ were appeared after $2 \mathrm{~min}$, which indicates that $\mathrm{C}_{3} \mathrm{~N}_{4}-4 \mathrm{~h}$ possess stronger adsorption ability than bulk g- $\mathrm{C}_{3} \mathrm{~N}_{4}$. This could be attributed to the enlarged surface areas of $\mathrm{C}_{3} \mathrm{~N}_{4}-4 \mathrm{~h}$, which accelerate the absorption process and enhance the absorption of NO.

Fig. 10b shows the spectra photocatalytic NO oxidation on $\mathrm{C}_{3} \mathrm{~N}_{4}$-4h during visible irradiation in time sequence. The new adsorption bands of reaction intermediates $\left(\mathrm{NO}_{2}\right.$ (at 2821, 2881, 2945 and $3463 \mathrm{~cm}^{-1}$ ), ${ }^{36} \mathrm{NOH}$ (at $1113 \mathrm{~cm}^{-1}$ ), ${ }^{41} \mathrm{~N}_{2} \mathrm{O}_{5}$ (866 and $\left.\left.902 \mathrm{~cm}^{-1}\right),{ }^{36} \mathrm{~N}_{2} \mathrm{O}_{3}\left(961 \mathrm{~cm}^{-1}\right)^{36}\right)$ and final products nitrates (1002 and $\left.1038 \mathrm{~cm}^{-1}\right)^{36,40}$ can be detected. The photocatalytic reaction process on bulk g- $\mathrm{C}_{3} \mathrm{~N}_{4}$ and $\mathrm{C}_{3} \mathrm{~N}_{4}-4 \mathrm{~h}$ exhibited similar behaviour and the mechanism was also applied to $\mathrm{C}_{3} \mathrm{~N}_{4}-4 \mathrm{~h}$. Obviously, the intensity of nitrate adsorption bands is stronger than the bulk g- $\mathrm{C}_{3} \mathrm{~N}_{4}$. This indicates the $\mathrm{C}_{3} \mathrm{~N}_{4}-4 \mathrm{~h}$ has higher photocatalytic oxidation ability, which leads to the production of more active species, promoting $\mathrm{NO}_{x}$ transformation from NO to final products of nitrates or nitrites.
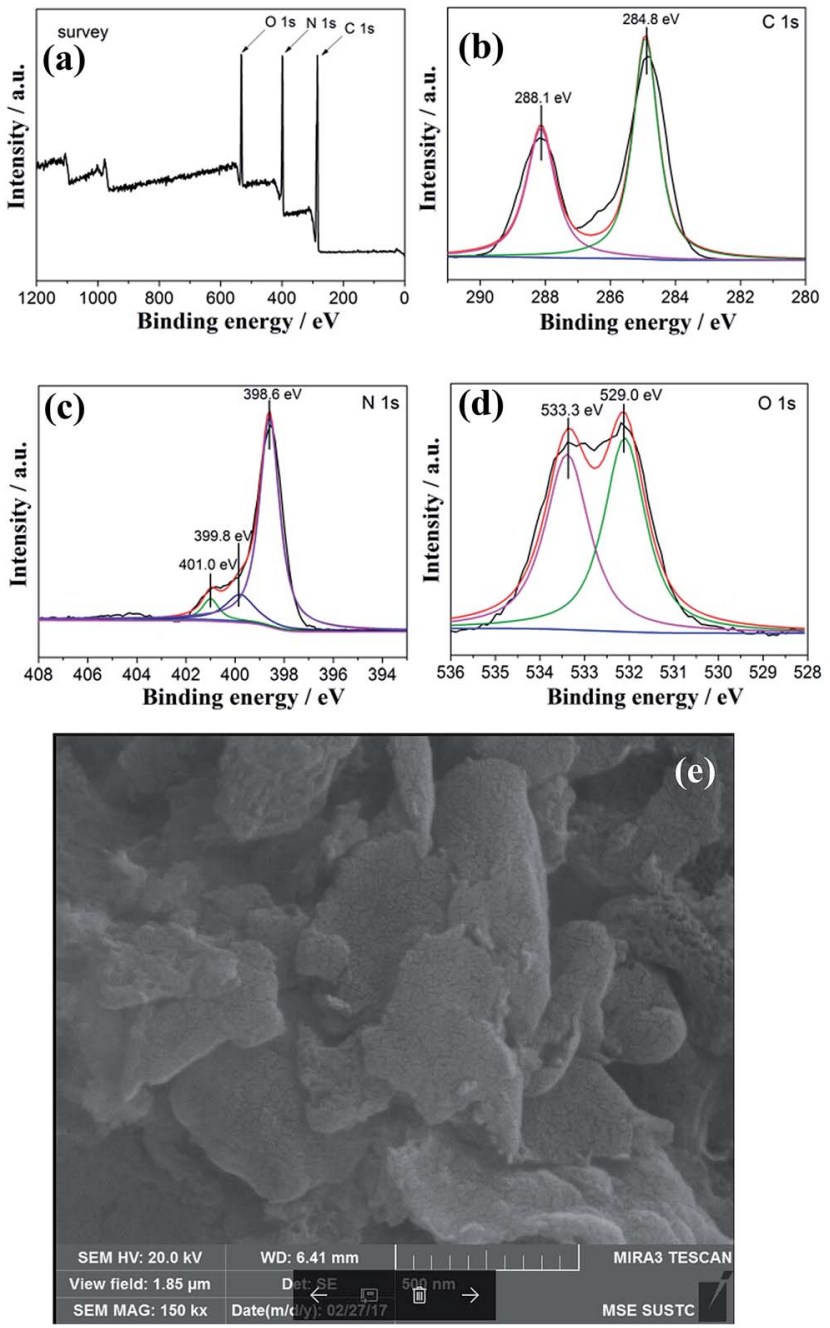

Fig. 11 XPS spectra of survey (a), C 1s (b), N 1s (c), O 1s (d) and SEM image (e) of $\mathrm{C}_{3} \mathrm{~N}_{4}-4 \mathrm{~h}$ after recycled tests. 
To determine the stability of the $\mathrm{C}_{3} \mathrm{~N}_{4}-4 \mathrm{~h}$, we carried out the XPS and SEM measurements of $\mathrm{C}_{3} \mathrm{~N}_{4}-4 \mathrm{~h}$ after recycled photocatalytic test is shown in Fig. 11. The XPS measurements (Fig. 11a-d) show that the similar presence of $\mathrm{C}, \mathrm{N}$ and $\mathrm{O}$ in the $\mathrm{C}_{3} \mathrm{~N}_{4}-4 \mathrm{~h}$ after photocatalytic test. ${ }^{35}$ Fig. 10 shows the typical high resolution XPS spectra for $\mathrm{C}, \mathrm{N}$ and $\mathrm{O}$ elements, indicating that the chemical structure of $\mathrm{C}_{3} \mathrm{~N}_{4}-4 \mathrm{~h}$ does not change after repeated irradiations. It can be observed from the SEM image (Fig. 11e) that the morphological structure of $\mathrm{C}_{3} \mathrm{~N}_{4}-4 \mathrm{~h}$ is wellmaintained.

\section{Conclusions}

In summary, the thermally treated ultra-thin porous g- $\mathrm{C}_{3} \mathrm{~N}_{4}$ nanosheets were synthesized by a facile method. The porous $\mathrm{g}$ $\mathrm{C}_{3} \mathrm{~N}_{4}$ nanosheets exhibited remarkably enhanced photocatalytic activity in NO removal under visible light irradiation owing to the cooperation of the increased surface area and pore structure, enhanced redox ability and improvement of effective charge separation. The in situ DRIFT was employed to monitor the evolution of reaction intermediates basing on the timedependent photocatalytic reaction. A mechanism for photocatalytic $\mathrm{NO}$ oxidation with $\mathrm{g}-\mathrm{C}_{3} \mathrm{~N}_{4}$ was proposed. The porous g$\mathrm{C}_{3} \mathrm{~N}_{4}$ nanosheets demonstrated enhanced adsorption performance and oxidation ability for NO. The present work could provide new insights into the understanding of $\mathrm{g}-\mathrm{C}_{3} \mathrm{~N}_{4}$ photocatalysis for NO removal.

\section{Acknowledgements}

This research was financially supported by National Natural Science Foundation of China (21501016, 51478070, 51108487 and 21676037), the Innovative Research Team of Chongqing (CXTDG201602014), Natural Science Foundation of Chongqing (cstc2016jcyjA0481 and cstc2015jcyjA0061), and the project from Chongqing Education Commission (KJ1600625, KJ1500601 and Kj1500637).

\section{Notes and references}

1 W. J. Ong, L. L. Tan, H. N. Yun, S. T. Yong and S. P. Chai, Chem. Rev., 2016, 116, 7159-7329.

2 G. Liu, P. Niu, C. Sun, S. C. Smith, Z. Chen, G. Q. Lu and H. M. Cheng, J. Am. Chem. Soc., 2010, 132, 11642-11648.

3 Y. Zheng, Y. Jiao, J. Chen, J. Liu, J. Liang, A. Du, W. Zhang, Z. Zhu, S. C. Smith and M. Jaroniec, J. Am. Chem. Soc., 2011, 133, 20116-20119.

4 J. Liang, Y. Zheng, J. Chen, J. Liu, D. Hulicova-Jurcakova, M. Jaroniec and S. Z. Qiao, Angew. Chem., Int. Ed., 2012, 124, 3958-3962.

5 S. Zhang, H. Gao, X. Liu, Y. S. Huang, X. Xu, N. S. Alharbi, T. Hayat and J. X. Li, ACS Appl. Mater. Interfaces, 2016, 8, 35138-35149.

6 S. Zhang, J. Li, X. Wang, Y. Huang, M. Zeng and J. Xu, ACS Appl. Mater. Interfaces, 2014, 6, 22116-22125.

7 S. Zhang, J. Li, X. Wang, Y. Huang, M. Zeng and J. Xu, J. Mater. Chem. A, 2015, 3, 10119-10126.
8 S. Cao, J. Low, J. Yu and M. Jaroniec, Adv. Mater., 2015, 46, 2150-2176.

9 Q. Han, B. Wang, Y. Zhao, C. Hu and L. Qu, Angew. Chem., Int. Ed., 2015, 54, 11433-11437.

10 L. Yu, X. Zhang, C. Zhuang, L. Lin, R. Li and T. Peng, Phys. Chem. Chem. Phys., 2014, 16, 4106.

11 S. Samanta, S. Martha and K. Parida, ChemCatChem, 2014, 6, 1453-1462.

12 X. Bai, R. Zong, C. Li, D. Liu, Y. Liu and Y. Zhu, Appl. Catal., $B, 2014,147,82-91$.

13 O. Fontellescarceller, M. J. Mu ozbatista, M. Fernandezgarcia and A. Kubacka, ACS Appl. Mater. Interfaces, 2015, 6, 22-25.

14 X. Wang, G. Zhang, Z. A. Lan, L. Lin and S. Lin, Chem. Sci., 2016, 7, 3062-3066.

15 Z. Ding, X. Chen, A. Markus and X. Wang, ChemSusChem, 2011, 4, 274-281.

16 Z. Li, C. Kong and G. Lu, J. Phys. Chem. C, 2015, 120, 56-63. 17 L. Gu, J. Wang, Z. Zou and X. Han, J. Hazard. Mater., 2014, 268, 216.

18 M. Xu, L. Han and S. Dong, ACS Appl. Mater. Interfaces, 2013, 5, 12533-12540.

19 P. Niu, L. Zhang, G. Liu and H. M. Cheng, Adv. Funct. Mater., 2012, 22, 4763-4770.

20 F. Dong, Y. Li, Z. Wang and W. K. Ho, Appl. Surf. Sci., 2015, 358, 393-403.

21 Y. Sun, T. Xiong, Z. Ni, J. Liu, F. Dong, W. Zhang and W. K. Ho, Appl. Surf. Sci., 2015, 358, 356-362.

22 F. Dong, Z. Wang, Y. Li, W. K. Ho and S. C. Lee, Environ. Sci. Technol., 2014, 48, 10345-10353.

23 Z. Wang, W. Guan, Y. Sun, F. Dong, Y. Zhou and W. K. Ho, Nanoscale, 2015, 7, 2471-2479.

24 H. Li, X. Wu, S. Yin, K. Katsumata and Y. Wang, Appl. Surf. Sci., 2016, 392, 531-539.

25 X. Wang, K. Maeda, A. Thomas, K. Takanabe, G. Xin, J. M. Carlsson, K. Domen and M. Antonietti, A metal-free polymeric photocatalyst for hydrogen production from water under visible light, Nat. Mater., 2009, 8, 76-80.

26 X. Yang, F. Qian, G. Zou, M. Li, J. Lu, Y. Li and M. Bao, Appl. Catal., B, 2016, 193, 22-35.

27 A. P. Alivisatos, Semiconductor clusters, nanocrystals, and quantum dots, Science, 1996, 271, 933-937.

28 H. G. Kim, P. H. Borse, W. Choi and J. S. Lee, Angew. Chem., 2005, 44, 4585-4589.

29 F. Dong, Z. Zhao, T. Xiong, Z. Ni, W. Zhang, Y. Sun and W. K. Ho, ACS Appl. Mater. Interfaces, 2013, 5, 11392-11401.

30 T. Sano, S. Tsutsui, K. Koike, T. Hirakawa, Y. Teramoto, N. Negishi and K. Takeuchi, J. Mater. Chem. A, 2013, 1, 6489-6496.

31 F. Dong, Z. Wang, Y. Sun, W. K. Ho and H. Zhang, J. Colloid Interface Sci., 2013, 401, 70-79.

32 G. Liu, P. Niu, L. Wang, G. Q. Lu and H. M. Cheng, Catal. Sci. Technol., 2011, 1, 222-225.

33 G. Liu, C. Sun, H. G. Yang, S. C. Smith, L. Wang, G. Q. Lu and H. M. Cheng, Chem. Commun., 2010, 46, 755-757.

34 J. Pan, G. Liu, G. Q. Lu and H. M. Cheng, Angew. Chem., Int. Ed., 2011, 50, 2133-2137. 
35 C. Liu, Y. Zhang, F. Dong, X. Du and H. Huang, J. Phys. Chem. C, 2016, 10381-10389.

$36 \mathrm{P}$. Jussieu, Characterization of Nitrogen Oxides by Vibrational Spectroscopy, Inorg. Chem., 1982, 466-509.

37 J. C. S. Wu and Y. T. Cheng, J. Catal., 2006, 237, 393-404.

38 K. I. Hadjiivanov, Catal. Rev., 2007, 42(1\&2), 71-144.

39 K. Hadjiivanov, V. Avreyska, A. Dimitar Klissurski and T. Marinova, Langmuir, 2002, 18, 1619-1625.
40 T. Weingand, S. Kuba, K. Hadjiivanov and H. Knzinger, J. Catal., 2002, 209, 539-546.

41 M. Kantcheva, J. Catal., 2001, 204, 479-494.

42 W. Cui, X. Li, C. Gao, F. Dong and X. Chen, Catal. Today, 2016, 67-76.

43 Z. Zhao, Y. Sun, Q. Luo, F. Dong, H. Li and W. K. Ho, Sci. Rep., 2015, 5, 14643. 